SABINA STASZCZYK

ALEKSANDRA TOKARZ

Uniwersytet Jagielloński

Instytut Psychologii

\title{
ZWIĄZKI MIĘDZY WSKAŹNIKAMI PRACOHOLIZMU I WYPALENIA ZAWODOWEGO U SPECJALISTÓW ORAZ MENEDŻERÓW
}

\begin{abstract}
Celem badania było: (1) potwierdzenie przewidywanych, pozytywnych związków pracoholizmu z wypaleniem; (2) eksploracja powiązań pomiędzy wskaźnikami pracoholizmu, wypalenia zawodowego a stażem pracy; (3) zbudowanie i empiryczna weryfikacja modelu strukturalnego jako próby uporządkowania relacji między mierzonymi zmiennymi. Badania przeprowadzono wśród pracowników umysłowych dużej firmy działającej na rynku polskim. Wyniki częściowo potwierdziły hipotezę: tylko zadowolenie i nierównowaga w działaniu wykazywały istotne związki z obydwoma skalami wypalenia. Najsilniejszym negatywnym predyktorem składowych wypalenia było zadowolenie z pracy. Analizy korelacji i regresji były podstawą modelu wyjaśniającego wyczerpanie i brak zaangażowania, zmiennymi wyjaśniającymi były wskaźniki pracoholizmu i staż pracy.
\end{abstract}

Słowa kluczowe: pracoholizm, wypalenie zawodowe, konflikt praca-życie, wykorzystanie czasu, staż pracy.

„Aby się wypalić, trzeba najpierw płonąć”, napisała Pines (1993, s. 41), co implikuje istnienie związków przyczynowo-skutkowych (Schaufeli, Taris i van Rhenen, 2008) między pracoholizmem i wypaleniem zawodowym. Wskazała na to Maslach (1986), nazywając pracoholizm główną przyczyną wypalenia zawodowego. Obecny stan badań nie pozwala jednoznacznie potwierdzić tej tezy. Większość dotychczasowych wyników odnoszących się do związków między wypaleniem i pracoholizmem pochodzi bowiem z badań nieeksperymentalnych (Andreassen, Ursin i Eriksen, 2007; Guglielmi, Simbula, Schaufeli i Depolo, 2012; Schaufeli, Bakker, van der Heijden i Prins, 2009; Schaufeli i in., 2008;

Adres do korespondencji: SABINA STASZCZYK - Instytut Psychologii, Wydział Filozoficzny, Uniwersytet Jagielloński, ul. Jaremy 14a/46, 31-318 Kraków; e-mail: sabina.staszczyk@ gmail.com 
Taris, Schaufeli i Verhoven, 2005; van Beek, Hu, Schaufeli, Taris i Schreurs, 2012; van Beek, Taris i Schaufeli, 2011). Jednakże wyniki badań wykorzystujących modelowanie równań strukturalnych wspierają zasadność postulowanego kierunku zależności między tymi dwoma syndromami (Schaufeli, Bakker i in., 2009; Taris i in., 2005).

\section{PRACOHOLIZM}

Wielu współczesnych autorów zajmujących się pracoholizmem (np. Dudek, 2008; Golińska, 2008; Hornowska i Paluchowski, 2007; Malinowska, 2014; Patel, Bowler, Bowler i Methe, 2012; Szpitalak, 2012; Wojdyło, 2010, 2013) wskazuje, że brakuje spójności między badaniami, a dyskusje co do definicji skutkują stosowaniem odmiennych wskaźników oraz narzędzi diagnozy. Otrzymuje się zatem zróżnicowane dane na temat funkcjonowania psychofizycznego, zawodowego czy społecznego pracoholików (por. Malinowska, Jochymek i Tokarz, 2011; Patel i in., 2012).

Metaanaliza dokonana przez Patel i współautorów (2012) wykazała, że dwa najczęściej wykorzystywane narzędzia do badania pracoholizmu - WorkBAT i WART - „koncentrują się na różnych aspektach pracoholizmu, co następnie prowadzi do tego, że są inaczej powiązane z różnymi kryteriami pracy” (s. 2). Na przykład pracoholizm mierzony przez WART i WorkBAT silnie koreluje ze zdrowiem psychicznym i stresem zawodowym, natomiast pracoholizm mierzony za pomocą WorkBAT dodatkowo wykazuje silne związki z charakterystykami pracy, zaangażowaniem, sukcesem zawodowym i wysiłkiem (Patel i in., 2012).

Niespójne wyniki dotyczące funkcjonowania pracoholików powodują, że niezbędne jest ujmowanie pracoholizmu jako syndromu mającego strukturę wielowymiarową (por. Aziz i Zickar, 2006; Malinowska, 2014; Szpitalak, 2012). Odwołujemy się więc do współczesnej propozycji $\mathrm{Ng}$, Sorensen i Feldmana (2007) definiującej pracoholików jako „osoby, których emocje, myśli i zachowanie są silnie zdominowane przez ich pracę" (s. 114). Wielowymiarowy model odnosi się do trzech procesów psychicznych, jakie należy analizować w każdym uzależnieniu (por. Smith i Seymour, 2004): zachowanie, poznanie i afekt. Na tej podstawie zdecydowano o przyjęciu poznawczych (przymus do pracy) i emocjonalnych (zadowolenie, zaangażowanie) czynników z koncepcji Spence i Robbins (1992) oraz poszerzeniu ich o wskaźniki określające zaburzenie równowagi między pracą a życiem prywatnym. 
Wyniki badań uwzględniające oszacowania pracowników na temat wykorzystania czasu dostarczają danych świadczących o słuszności włączenia do badań także zmiennych określających zaburzenia równowagi między życiem zawodowym a prywatnym. Malinowska (2010) podjęła próbę wykrycia kryteriów, których spełnienie może świadczyć o pracoholizmie lub zwiększeniu jego ryzyka. Analizy statystyczne wykazały, że w definiowaniu pracoholizmu istotny jest czas poświęcany na pracę i myślenie o niej, jak również brak równowagi w czasie poświęcanym na życie zawodowe w porównaniu z czasem spędzanym na pozostałych aktywnościach.

Podsumowując, przyjęty wielowymiarowy model pracoholizmu uwzględnia najbardziej znaczące elementy dotychczas stosowane do definiowania tego zjawiska, tj. poczucie przymusu do pracy (np. Dudek, 2008; Golińska, 2008; Hornowska i Paluchowski, 2007; Malinowska, 2014; Schaufeli i in., 2008; Spence i Robbins, 1992; Szpitalak, 2012; Wojdyło, 2013), zaangażowanie w pracę (Malinowska, 2014; Spence i Robbins, 1992), zadowolenie z pracy (Malinowska, 2014; Spence i Robbins, 1992), zaburzenie równowagi między życiem zawodowym i prywatnym (np. Andreassen, Griffiths, Hetland i Pallesen, 2012; Aziz, Uhrich, Wuensch i Swords, 2013; Dudek, 2008; Griffiths, 2005; Malinowska, 2014; Ng i in., 2007), w tym czas poświęcany na pracę i myślenie o niej. Trójwymiarowa struktura pracoholizmu (wymiar poznawczy, behawioralny i emocjonalny) została potwierdzona w badaniach Malinowskiej (2014), zmienne mierzące pracoholizm okazały się dobrymi wskaźnikami założonego konstruktu teoretycznego.

Zauważmy również, że przyjęty przez nas model pracoholizmu równoważy pato- i salutogenetyczne podejście (Antonovsky, 1979) do omawianego zaburzenia. Przyjęcie obu perspektyw umożliwia komplementarne ujęcie zarówno pozytywnych, jak i negatywnych aspektów pracoholizmu, nie przesądzając o dominacji żadnego $\mathrm{z}$ nich (jak to ma miejsce $\mathrm{w}$ ujęciach traktujących pracoholizm jako uzależnienie lub pozytywne zaangażowanie w pracę, por. Malinowska, 2014). Takie postępowanie wydaje się zasadne $\mathrm{z}$ uwagi na dostępne dane empiryczne (np. Bonebright, Clay i Ankenmann, 2000; van Beek i in., 2011) oraz wciąż wczesny etap rozwoju wiedzy o uzależnieniach czynnościowych (por. Juczyński, 2008). 


\section{WYPALENIE ZAWODOWE}

Opis modelu wymagań i zasobów zawodowych (Demerouti, Bakker, Nachreiner i Schaufeli, 2001), wybranego przy projektowaniu niniejszego badania, należy poprzedzić przedstawieniem aktualnych definicji wypalenia (Maslach, 1993/2000).

Maslach i Jackson (1981) określają wypalenie jako ,syndrom emocjonalnego wyczerpania i cynizmu występujący często wśród osób pracujących z innymi ludźmi w pewien określony sposób" (s. 99), zakładający bliski kontakt emocjonalny z klientem. Wypalenie powinno zatem dotyczyć wyłącznie zawodów społecznych (Maslach i Schaufeli, 1993). Wykazano jednak, że kontakt z klientem stanowi słabszy korelat wypalenia niż inne właściwości wymagań zawodowych, takie jak np. przeciążenie pracą, presja czasu (Schaufeli i Enzmann, 1998).

Objęcie pojęciem wypalenia różnych zawodów doprowadziło do przedefiniowania tego syndromu. Pierwsze kryterium - emocjonalne wyczerpanie, jako cecha centralna wypalenia, nie uległo zmianom. Jak zauważa Maslach (1993/ 2000), wyczerpanie jest koniecznym, ale niewystarczającym warunkiem wypalenia. Osoba wypalona doświadcza również, jeżeli pracuje w zawodzie społecznym, depersonalizacji, skutkiem czego dystansuje się od klientów i ma obniżone poczucie dokonań osobistych. Dzięki uwzględnieniu zawodów niespołecznych pojęcie depersonalizacji (klientów) zostało zastąpione cynizmem, rozumianym jako dystansowanie się od pracy w ogóle. Kryterium obniżonego poczucia dokonań osobistych zostało rozszerzone na ogólny brak efektywności. Kolejny model wypalenia zawodowego, z założenia nieograniczający wypalenia do zawodów społecznych, autorstwa Demerouti i współautorów (2001), głosi, że wymiary wypalenia opisane przez Maslach i Jackson (1981) - wyczerpanie emocjonalne i depersonalizacja - mogą być zamienione na bardziej ogólne: wyczerpanie, jako konsekwencję intensywnego wysiłku emocjonalnego, poznawczego i fizycznego, oraz brak zaangażowania, czyli dystansowanie się od wykonywanej pracy, negatywne nastawienie do niej. Te dwa wymiary uznano za kluczowe (Green, Walkey i Taylor, 1991). Korelują one ze sobą silniej niż z trzecim czynnikiem zaproponowanym przez Maslach i Jackson (1981) - obniżonym poczuciem dokonań osobistych (Lee i Ashforth, 1996). Dodatkowo, niewymieniany w modelu Demerouti i współautorów (2001) wymiar obniżonego poczucia dokonań osobistych nie różnicuje osób wypalonych zawodowo od niewypalonych (Schaufeli, Bakker, Hoogduin, Schaap i Kladler, 2001). 


\section{STAN BADAŃ NAD ZWIĄZKAMI MIĘDZY PRACOHOLIZMEM I WYPALENIEM}

Większość dotychczasowych badań odnoszących się dowypalenia i pracoholizmu skupiała się na określaniu związków korelacyjnych między tymi dwoma konstruktami. Są one pozytywne, głównie między pracoholizmem a wyczerpaniem (Andreassen i in., 2007; Guglielmi i in., 2012; Schaufeli i in., 2008; Taris i in., 2005; van Beek i in., 2012). W odniesieniu natomiast do związków składowych pracoholizmu $\mathrm{z}$ wypaleniem zawodowym znajdujemy sprzeczne dane. W zależności od badania, najsilniejsze związki notowane są między wypaleniem i emocjonalnymi (Andreassen i in., 2007), poznawczymi (Burke i Matthiesen, 2004; Schaufeli, Bakker i in., 2009; Schaufeli i in., 2008) lub behawioralnymi (Guglielmi i in., 2012; van Beek i in., 2012) wskaźnikami pracoholizmu (zob. Tabela 1).

Tabela 1

Zestawienie badań sity związów między wskaźnikami pracoholizmu i wypalenia zawodowego (opracowanie własne)

\begin{tabular}{|c|c|c|c|}
\hline $\begin{array}{l}\text { Autor, } \\
\text { rok }\end{array}$ & Osoby badane & Narzędzia pomiarowe & Wyniki \\
\hline & \multicolumn{3}{|c|}{ Najsilniejsze zwiazki między wypaleniem i emocjonalnymi wskaźnikami pracoholizmu } \\
\hline \multirow[t]{3}{*}{$\begin{array}{l}\text { Andreas- } \\
\text { sen } \\
\text { i in. } \\
(2007)\end{array}$} & \multirow[t]{2}{*}{$\begin{array}{l}235 \text { norweskich pra- } \\
\text { cowników banku, } 57 \% \\
\text { kobiet } \\
\text { Średnia wieku: } 44 \text { lata } \\
(S D=9,7) .\end{array}$} & $\begin{array}{l}\text { Pracoholizm: norweska wer- } \\
\text { sja (Burke, Richardsen i Mar- } \\
\text { tinussen, 2002) Workaholism } \\
\text { Battery Scale (WorkBAT; } \\
\text { Spence i Robbins, 1992) }\end{array}$ & \multirow[t]{2}{*}{ 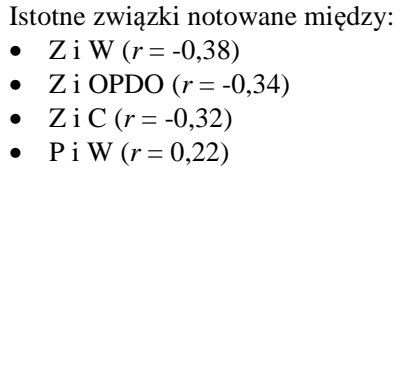 } \\
\hline & & $\begin{array}{l}\text { Wypalenie: norweska wersja } \\
\text { (brak danych o autorach } \\
\text { adaptacji) Maslach Burnout } \\
\text { Inventory - General Survey } \\
\text { (MBI-GS; Schaufeli, Leiter, } \\
\text { Maslach i Jackson, 1996) }\end{array}$ & \\
\hline & \multicolumn{3}{|c|}{ Najsilniejsze zwiazki między wypaleniem i poznawczymi wskaźnikami pracoholizmu } \\
\hline \multirow[t]{2}{*}{$\begin{array}{l}\text { Burke } \\
\text { i Mat- } \\
\text { thiesen } \\
(2004)\end{array}$} & \multirow{2}{*}{$\begin{array}{l}211 \text { norweskich dzien- } \\
\text { nikarzy, 33\% kobiet } \\
\text { Wiek: } 21 \% \text { poniżej } 29 \\
\text { lat; } 45 \%-30-39 ; 18 \%- \\
\text { 40-49; } 15 \%-50-59 ; 2 \% \\
\text { - powyżej } 60 \text { lat }\end{array}$} & $\begin{array}{l}\text { Pracoholizm: norweska wer- } \\
\text { sja (Burke i in., 2002) Work- } \\
\text { BAT (Spence i Robbins, } \\
\text { 1992) }\end{array}$ & \multirow{2}{*}{$\begin{array}{l}\text { Pracoholicy Właściwi i Entuzja- } \\
\text { styczni osiągają wyższe wyniki } \\
\text { w W i C niż Entuzjaści Pracy. Do- } \\
\text { łączając do zagrożonych także Pra- } \\
\text { cowników Pozbawionych Złudzeń } \\
\text { (również wyższy poziom na dwóch } \\
\text { skalach wypalenia) wnioskujemy, że } \\
\text { wyższe wyniki w zakresie wypale- } \\
\text { nia osiągają osoby charakteryzujące } \\
\text { się wysokim poziomem P }\end{array}$} \\
\hline & & $\begin{array}{l}\text { Wypalenie: norweska wersja } \\
\text { (brak informacji o autorach } \\
\text { adaptacji) MBI-GS (Schaufeli } \\
\text { i in., 1996) }\end{array}$ & \\
\hline
\end{tabular}




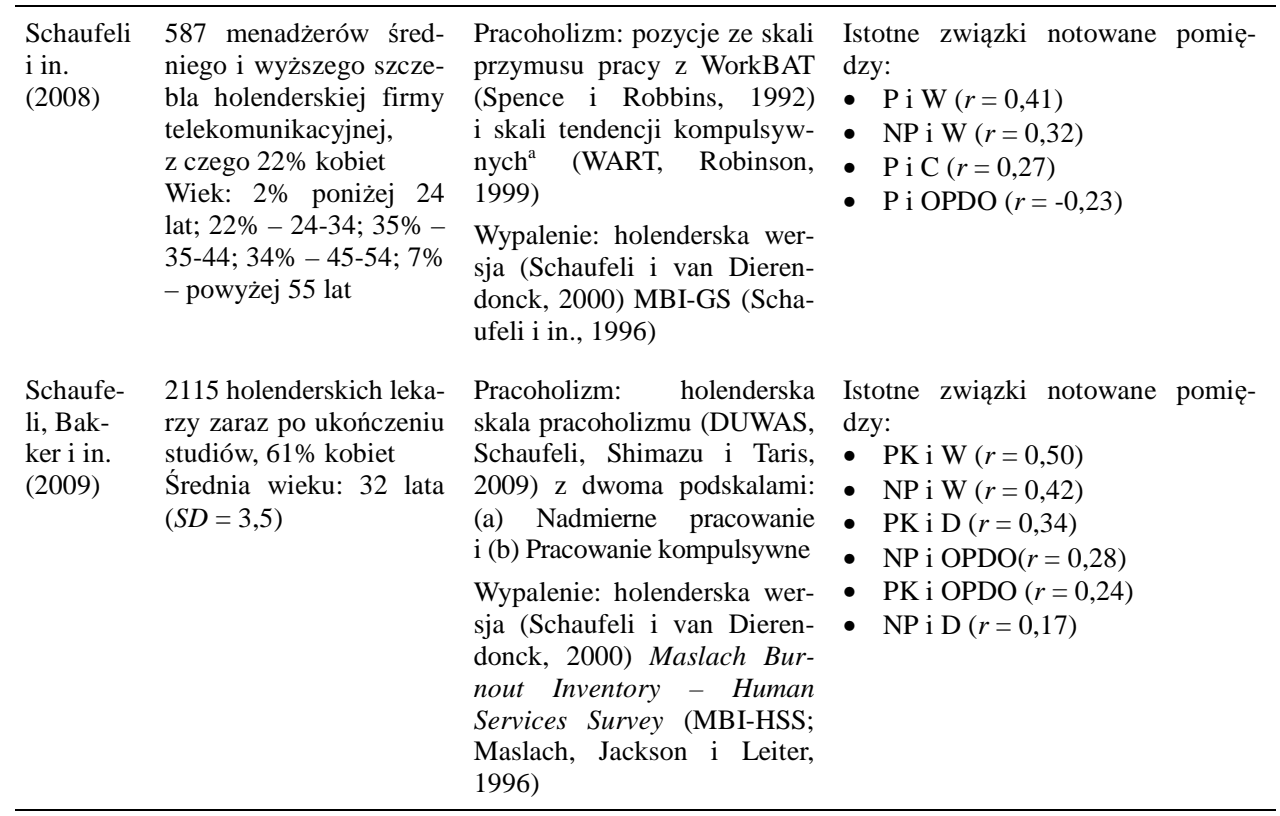

Najsilniejsze zwiąki między wypaleniem i behawioralnymi wskaźnikami pracoholizmu

\begin{tabular}{|c|c|c|c|}
\hline $\begin{array}{l}\text { Gugliel- } \\
\text { mi i in. } \\
\text { (2012) }\end{array}$ & $\begin{array}{l}166 \text { dyrektorów wło- } \\
\text { skich szkół, } 67 \% \text { kobiet } \\
\text { Wiek: } 15 \% \text { poniżej } 50 \\
\text { lat; } 44 \%-50-55 ; 29 \% \\
-56-60 ; 12 \% \text { powyżej } \\
60 \text { lat }\end{array}$ & $\begin{array}{l}\text { Pracoholizm: włoska wersja } \\
\text { (Guglielmi i in., 2012) } \\
\text { DUWAS (Schaufeli, Shima- } \\
\text { zu i in., 2009) } \\
\text { Wypalenie: włoska wersja } \\
\text { (Borgogni, Galati, Petitta } \\
\text { i Centro Schweitzer, 2005) } \\
\text { MBI-GS (Schaufeli i in., } \\
\text { 1996) }\end{array}$ & $\begin{array}{l}\text { Istotne związki notowane pomię- } \\
\text { dzy: } \\
\text { - NP i W }(r=0,45) \\
\text { - PK i W }(r=0,25) \\
\text { - NP i C }(r=0,20) \\
\text { - PK i } C(r=0,17)\end{array}$ \\
\hline $\begin{array}{l}\text { van } \\
\text { Beek } \\
\text { i in. } \\
(2012)\end{array}$ & $\begin{array}{l}760 \text { pracowników chiń- } \\
\text { skich szpitali: } 544 \text { pie- } \\
\text { lęgniarzy, } 99 \% \text { kobiet; } \\
216 \text { fizjoterapeutów, } \\
61 \% \text { kobiet } \\
\text { Srednia wieku pielęg- } \\
\text { niarzy: } 29 \text { lat }(S D= \\
7,48) \text {, fizjoterapeutów- } \\
35 \text { lat }(S D=9,33)\end{array}$ & $\begin{array}{l}\text { Pracoholizm: chińska wersja } \\
\text { (van Beek i in., 2012) } \\
\text { DUWAS (Schaufeli, Shima- } \\
\text { zu i in., 2009) } \\
\text { Wypalenie: chińska wersja } \\
\text { (Van Beek i in., 2012) MBI- } \\
\text { GS (Schaufeli i in., 1996) }\end{array}$ & $\begin{array}{l}\text { Istotne związki notowane pomię- } \\
\text { dzy: } \\
\text { - NP i W }(r=0,43) \\
\text { - PK i W }(r=0,26) \\
\text { - NP i C }(r=0,26) \\
\text { - PK i C }(r=0,11)\end{array}$ \\
\hline
\end{tabular}

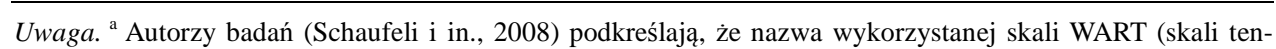
dencji kompulsywnych) jest myląca, ponieważ większość jej pozycji odnosi się do ciężkiej pracy, podczas gdy pozostałe pozycje dotyczą niezdolności do relaksu i poczucia winy z powodu niepracowania. W związku z tym wśród zmiennych wyróżniają oni (tamże) nadmierne pracowanie zamiast tendencji kompulsywnych.

$\mathrm{NP}$ - nadmierne pracowanie, $\mathrm{P}$ - przymus, PK - pracowanie kompulsywne, $\mathrm{Z}$ - zadowolenie, $\mathrm{C}$ - cynizm, $\mathrm{D}$ - depersonalizacja, OPDO - obniżone poczucie dokonań osobistych, $\mathrm{W}$ - wyczerpanie. 
Należy jednak podkreślić, że w badaniach (por. Tabela 1) pomijano emocjonalne (Guglielmi i in., 2012; Schaufeli, Bakker i in., 2009; Schaufeli i in., 2008; van Beek i in., 2012) lub behawioralne (Andreassen i in., 2007; Burke i Matthiesen, 2004) wskaźniki pracoholizmu, przez co brakuje danych ukazujących całą złożoność omawianych zjawisk.

\section{CELE BADANIA}

Celem badania było: (1) potwierdzenie przewidywanych, pozytywnych związków pracoholizmu z wypaleniem; (2) eksploracja powiązań między wskaźnikami pracoholizmu, wypalenia zawodowego a stażem pracy; (3) zbudowanie i empiryczna weryfikacja modelu strukturalnego jako próby uporządkowania relacji pomiędzy mierzonymi zmiennymi.

\section{METODA}

\section{Osoby badane}

W badaniu wzięło udział 210 osób (82 kobiet i 128 mężczyzn). Większość badanych to osoby młode $-\mathrm{w}$ wieku $M=28,62(S D=4,55)$, mające wykształcenie wyższe $(86,7 \%)$, niezarządzające zespołem $(76,7 \%)$, o stażu zawodowym krótszym niż 5 lat $(55,2 \%)$. Osoby badane pochodziły z jednego miejsca pracy.

\section{Materiały}

W pomiarze pracoholizmu posłużono się polską wersją skali WorkBAT (Spence i Robbins, 1992), opracowaną przez Malinowską, Tokarz i Gad (2010), oraz Inwentarzem Wykorzystania Czasu (Tokarz, Malinowska i Jochymek, 2014).

Workaholism Battery (WorkBAT). Narzędzie składa się z 15 stwierdzeń, do których osoby badane ustosunkowują się na 5-stopniowej skali $(1-z$ decydowanie się zgadzam; 5 - zdecydowanie się nie zgadzam). Poszczególne pozycje wchodzą w skład trzech wymiarów: (a) zaangażowanie w pracę $(\alpha=0,50)$, np. „Lubię wykorzystywać swój czas konstruktywnie, zarówno w pracy, jak i poza nią”; (b) przymus pracy ( $\alpha=0,74)$, np. „Czuję obowiązek, aby pracować ciężko nawet, jeśli nie sprawia mi to przyjemności”; (c) zadowolenie z pracy $(\alpha=0,67)$, np. „Lubię swoją pracę bardziej niż większość ludzi”. 
Ze względu na to, że - podobnie jak w innych badaniach (por. Andreassen i in., 2007; Kanai, Wakabayashi i Fling, 1996; McMillan, Brady, O’Driscoll i Marsh, 2002) - skala zaangażowania nie osiągnęła satysfakcjonującego poziomu rzetelności (najniższa dopuszczalna rzetelność: $\alpha=0,65$; De Vellis, 2003), wyłączono z analiz pozycje skali Zaangażowania. Dzięki tej operacji rzetelność dla narzędzia (zawierającego pozycje skali Zadowolenia i Przymusu) wyniosła 0,70 .

Inwentarz Wykorzystania Czasu. W inwentarzu wyróżniono 10 dziedzin życia człowieka (por. Klinger i Cox, 2004): sen, obowiązki domowe, życie towarzyskie, relaks, duchowość, praca, pasje, rodzina, doskonalenie zawodowe i inne dziedziny. Zadaniem osoby badanej jest określenie, ile godzin tygodniowo poświęca na działanie oraz myślenie o poszczególnych sferach życia. Opisywane narzędzie pozwala obliczyć: (a) nierównowagę między życiem zawodowym a prywatnym w działaniu (ND; $\alpha=0,68$ ) - wskaźnik behawioralny obejmujący sześć kryteriów diagnostycznych ${ }^{1}$. Jego natężenie określa liczba kryteriów spełnionych przez osobę badaną. Przykładowe kryterium ND to: „Poświęcanie na pracę 50 godzin w tygodniu lub więcej”; (b) nierównowagę między życiem zawodowym a prywatnym w myśleniu (NM; $\alpha=0,88)$ - wskaźnik poznawczy, na który składa się sześć kryteriów diagnostycznych, np. „Myślenie o pracy zajmuje min. 50\% czasu poświęcanego na myślenie o pozostałych dziedzinach życia". Dodatkowo narzędzie umożliwia oszacowanie czasu poświęcanego na pracę i myślenie o niej.

Oldenburski kwestionariusz wypalenia zawodowego. Do określenia poziomu wypalenia zawodowego wykorzystano polską wersję Oldenburskiego kwestionariusza wypalenia zawodowego (OLBI; Demerouti i in., 2001), opracowaną przez Masłowską (2008). Narzędzie składa się z 16 pozycji, po osiem pozycji na każdą skalę: (a) wyczerpanie $(\alpha=0,74)$, np. „Podczas pracy często czuję się wykończony/wykończona emocjonalnie"; (b) brak zaangażowania $(\alpha=0,78)$, np. „Czasem odczuwam niechęć do zadań, które muszę wykonać w pracy”. Zadaniem osoby badanej jest określenie, w jakim stopniu zgadza się ona z poszcze-

\footnotetext{
${ }^{1}$ Kryteria oblicza się na podstawie odpowiedzi osób badanych. Do ich wypracowania autorka narzędzia (Malinowska, 2010) wykorzystała klasyfikację - algorytmy drzew decyzyjnych, CRT (Breiman's C\&RT implementation), dostępne w pakiecie SPSS. Zewnętrznym kryterium trafności dla wskaźników były wyniki w podskalach narzędzia WorkBAT. Zastosowano, zgodnie z propozycją autorek Spence i Robbins (1992), podział na typ pracoholika właściwego i entuzjastycznego. Wskaźnik ND opracowano na podstawie wysokiego poziomu przymusu pracy i zadowolenia z pracy (wyniki te odpowiadały typowi pracoholika entuzjastycznego). Wskaźnik NM opracowano na podstawie wysokiego poziomu przymusu pracy i niskiego poziomu zadowolenia z pracy (wyniki te odpowiadały typowi pracoholika właściwego).
} 
gólnymi stwierdzeniami zgodnie z 4-stopniową skalą, gdzie 1 oznacza zdecydowanie się zgadzam, 4 - zdecydowanie się nie zgadzam. a Cronbacha dla narzędzia wyniosła 0,83 .

Pomiar zmiennych demograficznych i związanych z pracą. Były to: płeć, wiek, wykształcenie, stan cywilny, posiadanie dzieci, zarządzanie zespołem pracowników, tryb pracy (stałe godziny pracy vs system zmianowy), staż pracy w obecnej organizacji, na danym stanowisku, staż pracy ogółem.

\section{WYNIKI}

\section{Analizy wstępne}

Do analizy statystycznej zastosowano pakiet SPSS.

Rozkłady wyników skal WorkBAT i OLBI są normalne ( $d$ KołmogorowaSmirnowa $<0,05)$. Natomiast wyniki IWCz nie mają rozkładu normalnego. Zmienne o prawoskośnym rozkładzie zostały poddane logarytmizacji dziesiętnej. Dzięki tej transformacji spełnione jest założenie o normalności rozkładu zmiennych, istotne przy wykonywaniu regresji. Ponadto jest uzasadnione, aby wyniki interpretować jako przyrosty procentowe czasu poświęcanego na pracę lub myślenie o niej.

Opracowanie kontrastów dla wskaźników IWCz (rekodowanie zmiennej porządkowej na zmienną ciągłą). Większość osób badanych $(80,1 \%)$ nie spełnia żadnego z kryteriów nierównowagi między życiem zawodowym a prywatnym w myśleniu (NM), z kolei w odniesieniu do nierównowagi między życiem zawodowym a prywatnym w działaniu (ND) większość osób badanych $(52,7 \%)$ spełnia chociaż jedno z sześciu kryteriów. W związku z dużą różnicą między liczbą osób spełniających chociaż jedno kryterium a niespełniającymi żadnego, zdecydowano o rekodowaniu wskaźników. W każdym z nich wyodrębniono dwie kategorie: (a) osoby niespełniające żadnego z kryteriów, (b) osoby spełniające chociaż jedno kryterium. Następnie zbudowano kontrasty pomiędzy tymi kategoriami dla wskaźnika NM (kontrast NM - porównujący osoby utrzymujące i nieutrzymujące równowagi między życiem zawodowym a prywatnym w myśleniu) i wskaźnika ND (kontrast ND - porównujący osoby utrzymujące i nieutrzymujące równowagi między życiem zawodowym a prywatnym w działaniu).

Wypalenie. Wyniki jednoczynnikowych analiz wariancji wykazały, że poziom wypalenia nie był istotnie różny wśród osób o odmiennej płci $(F=0,55$, $p=0,46)$, stanie cywilnym $(F=2,00, p=0,14)$, wykształceniu $(F=0,45$, 
$p=0,64)$, mających dzieci lub nie $(F=1,37, p=0,24)$. Odnotowano także brak różnic w poziomie wypalenia między osobami pracującymi w stałych godzinach lub w systemie zmianowym $(F=0,05, p=0,83)$. Jedynymi zmiennymi związanymi z pracą, mającymi związek z poziomem wypalenia, był staż pracy w obecnej organizacji $(F=4,01, p=0,008)$, ale już nie staż pracy na obecnie zajmowanym stanowisku $(F=0,82, p=0,48)$ czy całościowy staż pracy $(F=2,40$, $p=0,052)$. Ze względu na to, że nie zakładano kierunku związku między wypaleniem a stażem pracy, przeprowadzono analizy post-hoc (test HSD Tukeya). Istotnie wyższe wyniki wypalenia zanotowano wśród osób, których staż w danej orga-nizacji w trakcie pomiaru nie był dłuższy niż sześć miesięcy, w porównaniu z osobami, których staż $\mathrm{w}$ danej organizacji mieścił się w granicach 2-5 lat $(p=0,004)$, oraz tymi, które pracowały $\mathrm{w}$ danej organizacji powyżej pięciu lat $(p=0,03)$.

Na podstawie powyższych wyników zdecydowano o rekodowaniu zmiennej staż na zmienną z dwoma kategoriami: (1) osoby pracujące krócej niż pół roku, (2) osoby pracujące pół roku lub dłużej. Następnie utworzono kontrasty - porównania pomiędzy wyróżnionymi dwoma kategoriami (kontrast dla stażu pracy). Analiza korelacji $r$ Pearsona wykazała, że kontrast dla stażu koreluje dodatnio wypaleniem $(r=0,20)$, w tym tylko z jedną jego skalą: brakiem zaangażowania $(r=0,25)$. Oznacza to, że osoby o stażu poniżej pół roku w porównaniu z osobami o dłuższym stażu wykazują mniejsze zaangażowanie i tym samym większe wypalenie.

Związki pracoholizmu z wypaleniem. Spośród wszystkich wskaźników pracoholizmu najsilniejsze związki $\mathrm{z}$ wypaleniem zanotowano dla zadowolenia $(r=-0,52)$. Zadowolenie koreluje ujemnie zarówno z wyczerpaniem $(r=-0,38)$, jak i brakiem zaangażowania $(r=-0,53)$. Spośród poznawczych wskaźników pracoholizmu jedynie przymus wykazuje związek ze skalą wyczerpania $(r=0,21)$. Z kolei kontrast $\mathrm{ND}^{2}$, jako jedyny behawioralny wskaźnik pracoholizmu, wykazuje negatywne związki z oboma skalami wypalania: $\mathrm{z}$ wyczerpaniem $(r=-0,22)$ i brakiem zaangażowania $(r=-0,26)$.

\section{Analizy główne}

W celu eliminacji możliwych źródeł zakłóceń oszacowań poniższych modeli kontroli poddano homoskedastyczność (stałość wariancji reszt), rozkład reszt modelu, współliniowość zmiennych. Na podstawie odległości Cooka wyselek-

\footnotetext{
${ }^{2}$ Kontrast ND - kontrast pomiędzy niespełnieniem żadnego kryterium nierównowagi w działaniu a spełnieniem chociaż jednego z nich (nierównowaga vs równowaga w działaniu).
} 
cjonowano przypadki odstające. Zdecydowano o usunięciu jednego z nich odległość Cooka dla tego odstającego przypadku była większa niż innych w modelu dla zmiennej zależnej wypalenie i wyczerpanie, co zwiększyło wartości współczynników modelu. Wartość pozostałych statystyk była akceptowalna $(V I F<1,08$, Tolerancja $>0,9)$.

Regresja liniowa. Przeprowadzono trzy analizy regresji liniowej, w których zmiennymi niezależnymi były wskaźniki pracoholizmu oraz kontrast dla stażu pracy. Istotnymi predyktorami wypalenia okazały się następujące zmienne (skorygowane $\left.R^{2}=0,31\right)$ : zadowolenie $(\beta=-0,49, t=-8,01, p<0,001)$, przymus $(\beta=0,13, t=2,22, p=0,03)$ oraz kontrast ND $(\beta=-0,15, t=-2,41, p=0,17)$. Wyczerpanie może być wyjaśniane przez (skorygowane $R^{2}=0,22$ ): zadowolenie $(\beta=-0,37, t=-5,72, p<0,001)$, przymus $(\beta=0,23, t=3,65, p<0,001)$ i kontrast ND $(\beta=-0,17, t=-2,55, p=0,01)$. Z kolei istotnymi predyktorami braku zaangażowania (skorygowane $\left.R^{2}=0,31\right)$ były: zadowolenie $(\beta=-0,48, t=-7,86$, $p<0,001)$, kontrast dla stażu pracy $(\beta=0,15, t=2,42, p=0,017)$ i przyrost czasu poświęcanego na myślenie o pracy $(\beta=0,12, t=2,01, p<0,045)$.

$\mathrm{Z}$ przedstawionych analiz wynika, że zadowolenie jest istotnym predyktorem wypalenia i jego dwóch składowych. Im wyższe wyniki zadowolenia, tym niższe wyczerpanie i brak zaangażowania. Wykazano również, że predyktorem wyczerpania jest przymus pracy (pozytywny związek) i kontrast ND. Osoby, które zachowują równowagę między życiem zawodowym a prywatnym, w działaniu uzyskują wyższe wyniki wyczerpania niż osoby spełniające chociaż jedno kryterium nierównowagi między życiem zawodowym a prywatnym w działaniu. $\mathrm{Z}$ kolei poziom braku zaangażowania obok zadowolenia może być wyjaśniany przez przyrost czasu poświęcanego na myślenie o pracy (związek dodatni) oraz kontrast dla stażu pracy, co oznacza, że osoby o stażu poniżej pół roku wykazują mniejsze zaangażowanie niż osoby o dłuższym stażu.

Modelowanie równań strukturalnych (analiza ścieżek). Na podstawie wyników analiz korelacji i regresji liniowej opracowano model strukturalny, w którym zmiennymi wyjaśnianymi było wyczerpanie i brak zaangażowania (zob. Rysunek 1). 


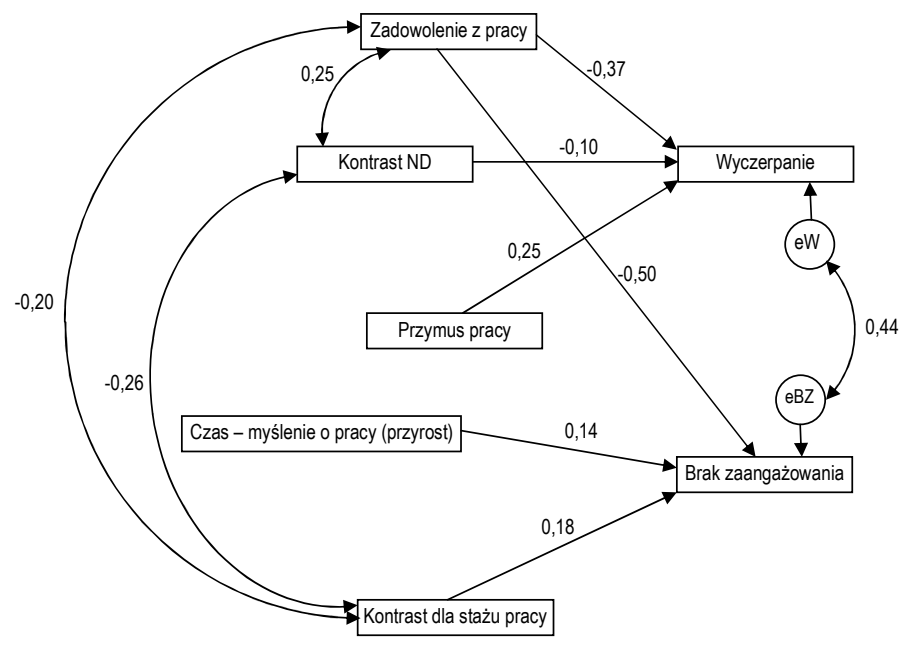

Rysunek 1. Model strukturalny wyjaśniający wariancje w zakresie wskaźników wypalenia: wyczerpania i braku zaangażowania. Wartości przy kolejnych ścieżkach przedstawiają standaryzowane wagi regresji modelu.

Uwaga. Kontrast ND - kontrast między niespełnieniem żadnego kryterium nierównowagi w działaniu a spełnieniem chociaż jednego z nich (nierównowaga vs równowaga w działaniu). Kontrast dla stażu pracy - kontrast między stażem pracy w organizacji wynoszącym mniej niż sześć miesięcy a więcej niż ten okres.

Model jest dobrze dopasowany, o czym świadczą wyniki testu chi-kwadrat $\left(\chi^{2}=11,87, d f=11, p=0,37\right)$ oraz indeksy dopasowania modelu $(\mathrm{TLI}=0,992$; RMSEA $=0,019$ ). Wartość Hoeltera (z prawdopodobieństwem < 0,05), wynosząca 345, potwierdza, że próba 209 osób jest akceptowalna (do odrzucenia przyjętego modelu niezbędna byłaby grupa o ponad połowę większa).

Analiza wielkości standaryzowanych efektów całkowitych wykazała, że zadowolenie wywiera największy negatywny wpływ ${ }^{3}$ zarówno na wyczerpanie $(-0,37)$, jak i na brak zaangażowania $(-0,50)$. Poziom wyczerpania, obok zadowolenia, zależy również od przymusu $(0,25)$ oraz kontrastu ND (osoby niespełniające żadnego z kryteriów ND wykazują większe natężenie wyczerpania niż osoby spełniające chociaż jedno z nich; -0,10). Na brak zaangażowania, oprócz zadowolenia, ma wpływ czas poświęcany na myślenie o pracy (im większy przyrost czasu spędzanego na myśleniu o pracy, tym mniejsze zaangażowanie; 0,14 )

\footnotetext{
${ }^{3} \mathrm{~W}$ modelach analizy ścieżek zakłada się, że relacje między zmiennymi wprowadzonymi do modelu są przyczynowe (Cwalina, 2000). Ze względu jednak na to, że prezentowane badania nie mają charakteru eksperymentalnego, ,pozytywna weryfikacja modelu nie jest dowodem, że zakładane w modelu relacje przyczynowe rzeczywiście występują, a jedynie, że model może być prawdziwy" (Cwalina, 2000, s. 17).
} 
oraz staż pracy (osoby o stażu do pół roku są mniej zaangażowane niż osoby pracujące w danej organizacji pół roku lub więcej; 0,18). Oszacowanie wyjaśnianej wariancji wskazuje, że czynniki wyjaśniają $28 \%$ wariancji zmiennej brak zaangażowania i $23 \%$ zmiennej wyczerpanie.

\section{DYSKUSJA WYNIKÓW}

Wypalenie zawodowe wyjaśniono poprzez różne wskaźniki pracoholizmu. Wyniki tylko częściowo potwierdziły występowanie dodatniej korelacji pracoholizmu z wypaleniem, co wcześniej zostało stwierdzone w badaniu pracowników holenderskich (Schaufeli, Bakker i in., 2009; Schaufeli i in., 2008; Taris i in., 2005), norweskich (Andreassen i in., 2007), włoskich (Guglielmi i in., 2012) czy chińskich (van Beek i in., 2012). W badaniu uwzględniliśmy poznawcze (przymus pracy, czas poświęcany na myślenie o pracy), behawioralne (równowaga między życiem zawodowym a prywatnym w działaniu, czas poświęcany na pracę) i emocjonalne (zadowolenie z pracy) komponenty pracoholizmu, spośród których tylko zadowolenie i nierównowaga w działaniu wykazywały istotne związki z obydwoma wskaźnikami wypalenia. Uważamy zatem, że rozpatrywanie związków między tymi zjawiskami powinno odbywać się na poziomie ich komponentów (por. McMillan i O’Driscoll, 2004), jak i wymiarów, gdyż - jak to zostanie wykazane poniżej - znacznie zwiększa możliwości porównywania wyników badań, w których uwzględniano różne wskaźniki pracoholizmu.

Spośród wszystkich składowych pracoholizmu najsilniejszy ujemny związek $\mathrm{z}$ wypaleniem ma zadowolenie $(-0,52)$. Zmienna ta jest najbardziej istotna w prognozowaniu zarówno wyczerpania, jak i braku zaangażowania. Podobne wyniki, ukazujące najsilniejsze związki wypalenia z emocjonalnymi wskaźnikami pracoholizmu, uzyskał Andreassen i współpracownicy (2007). Z kolei w innych badaniach najsilniejsze związki notowano między wypaleniem i poznawczym (Burke i Matthiesen, 2004; Schaufeli, Bakker i in., 2009; Schaufeli i in., 2008) lub behawioralnym wskaźnikiem pracoholizmu (Guglielmi i in., 2012; van Beek i in., 2012).

Istotne wydają się cztery kwestie. (1) Czas przeznaczany na pracę nie miał bezpośredniego związku z wypaleniem. Natomiast czas poświęcany na myślenie o pracy czy nierównowaga między życiem zawodowym a prywatnym w działaniu były istotnymi predyktorami kolejno: braku zaangażowania i wyczerpania (czyli składowych wypalenia zawodowego). Wyniki te są zgodne z danymi uzyskanymi przez innych badaczy (np. Beckers i in., 2004; Burke, 1999; van den 
Broeck i in., 2011) wskazującymi, że jakość wykorzystania czasu ma większe znaczenie dla odpowiedniego funkcjonowania jednostki niż sama jego ilość. (2) Chociaż wskaźniki poznawcze pracoholizmu wykazują związki z oboma komponentami wypalenia, to przymus pracy przyczynia się tylko (lub aż) do wzrostu wyczerpania u danej osoby (por. też van den Broeck i in., 2011), a nadmierne myślenie o pracy może przekładać się na brak zaangażowania, ale nie wyczerpanie. (3) Poziom braku zaangażowania może być wyjaśniany, obok zadowolenia i czasu poświęcanego na myślenie o pracy, również przez staż pracy, jako że osoby o stażu do pół roku wykazują mniejsze zaangażowanie niż osoby o dłuższym stażu. Negatywny związek między wypaleniem a stażem pracy uzyskała również Hamama (2012). Tym niemniej nasze wyniki wskazują, że niewłaściwe jest generalizowanie uzyskanego związku między stażem pracy i brakiem zaangażowania na wypalenie w ogóle. Zgodnie bowiem z modelem wymagań i zasobów (Demerouti i in., 2001) osobą wypaloną jest pracownik niezaangażowany i jednocześnie wyczerpany. (4) Dane wskazują, że osoby zachowujące równowagę między życiem zawodowym a prywatnym w działaniu uzyskują wyższe wyniki wyczerpania niż osoby mające zaburzoną równowagę, co można wyjaśnić koncepcją wyczerpywania ego wskutek nadmiernej kontroli, której autorem jest Baumeister (2002). Taka interpretacja jednak wykracza poza ramy omawianych kwestii i nie wydaje się wystarczająca.

Zastosowane metody mają ograniczenia. Po pierwsze, trzeba wskazać to, że badanie przeprowadzono wyłącznie wśród pracowników jednej organizacji, w której zatrudnieni są głównie młodzi ludzie $(M=28,61, S D=4,42)$, a staż pracy ponad połowy osób (55\%) był krótszy niż pięć lat. Statystyki te jednak nie zmniejszają szans na ujęcie w badaniu osób osiągających wysokie wyniki w zakresie wypalenia czy pracoholizmu. Maslach (1982) wskazywała, że wypalenie może się rozwinąć w ciągu pierwszych pięciu lat pracy. Co więcej, średnia dla przymusu i zadowolenia dla badanej próby nie różniła się istotnie od średniej w zakresie tych zmiennych w grupie studentów i absolwentów studiów Master of Business Administration (por. Malinowska, 2010). Młody wiek i brak zróżnicowania źródła pozyskiwania osób badanych nie zmniejsza zatem szans na uwzględnienie $\mathrm{w}$ badaniach osób o wysokim poziomie wypalenia czy pracoholizmu.

Po drugie, wszystkie zastosowane miary miały charakter samoopisowy. Liczne badania ukazują jednak, że pracoholicy mają właściwy obraz siebie w porównaniu z ocenami przedstawionymi na ich temat przez znajomych (Aziz i Zickar, 2006; McMillan, O’Driscoll i Brady, 2004) czy współpracowników (Burke i Ng, 2007). 
Po trzecie, na podstawie przeprowadzonego badania nie możemy wnioskować o relacjach przyczynowo-skutkowych. Zaprezentowany model strukturalny należy traktować jako rozszerzenie analizy regresji, umożliwiające łączne znajdowanie dopasowania dla dwóch powiązanych równań regresji wyjaśniających wariancje $\mathrm{w}$ zakresie wyczerpania i braku zaangażowania poprzez wskaźniki pracoholizmu i staż pracy (por. Garson, 2012). Jest to propozycja ukazania powiązań między składowymi wypalenia i wskaźnikami reprezentującymi trzy wymiary pracoholizmu. Wspiera ona prawdziwość postulowanego przez Maslach (1986; por. też: van den Broeck i in., 2011) kierunku zależności między tymi dwoma syndromami i uzasadnia konieczność analizy związku między pracoholizmem i wypaleniem na poziomie komponentów ujmujących różne wymiary badanych zjawisk. Do przyjęcia zaproponowanego modelu niezbędne jest powtórzenie badań na innej próbie i wykonanie badań podłużnych.

\section{LITERATURA CYTOWANA}

Andreassen, C. S., Griffiths, M. D., Hetland, J. i Pallesen, S. (2012). Development of a work addiction scale. Scandinavian Journal of Psychology, 53(3), 265-272.

Andreassen, C. S., Ursin, H. i Eriksen, H. R. (2007). The relationship between strong motivation to work, ,workaholism” and health. Psychology and Health, 22(5), 615-629.

Antonovsky, A. (1979). Health, stress and coping: New perspectives on mental and physical well-being. San Fransisco: Jossey Bass.

Aziz, S., Uhrich, B., Wuensch, K. L. i Swords, B. (2013). The Workaholism Analysis Questionnaire: Emphasizing work-life imbalance and addiction in the measurement of workaholism. Journal of Behavioral and Applied Management, 14(2), 71-86.

Aziz, S. i Zickar, M. J. (2006). A cluster analysis investigation of workaholism as a syndrome. Journal of Occupational Health Psychology, 11(1), 52-62.

Baumeister, R. F. (2002). Ego depletion and self-control failure. An energy model of the self's executive function. Self and Identity, 1(2), 129-136.

Beckers, D. G. J., van der Linden, D., Smulders, P. G. W., Kompier, M. A. J., van Veldhoven, M. J. P. M. i van Yperen, N. W. (2004). Working overtime hours: Relations with fatigue, work motivation, and the quality of work. Journal of Occupational and Environmental Medicine, 46(12), 1282-1289.

Bonebright, C. A., Clay, D. L. i Ankenmann, R. D. (2000). The relationships of workaholism with work-life confict, life satisfaction, and purpose in life. Journal of Counseling Psychology, 47(4), 469-477.

Borgogni, L., Galati, D., Petitta, L. i Centro Formazione A. Schweitzer (2005). Questionario di Check-up Organizzativo. Manuale. Firenze, Italy: Organizzazioni Speciali.

Burke, R. J. (1999). Workaholism in organizations: Gender differences. Sex Roles, 41(5-6), 333-345.

Burke, R. J. i Matthiesen, S. B. (2004). Workaholism among Norwegian journalists: Antecedents and consequences. Stress and Health, 20(5), 301-308. 
Burke, R. J. i Ng, E. S. (2007). Workaholic behaviors: Do colleagues agree? International Journal of Stress Management, 14(3), 312-320.

Burke, R. J., Richardsen, A. M. i Martinussen, M. (2002). Psychometric properties of Spence and Robbins' measures of workaholism components. Psychological Reports, 91(3f), 1098-1104.

Cwalina, W. (2000). Zastosowanie modelowania równań strukturalnych w naukach społecznych. W: Statystyka w badaniach naukowych oraz polska wersja Statistica Neural Network. Materiaty na seminaria organizowane przez. StatSoft Polska Sp. z o.o. 9 października $2000 \mathrm{r}$. $w$ Warszawie (s. 15-23). Kraków: StatSoft Polska.

Demerouti, E., Bakker, A. B., Nachreiner, F. i Schaufeli, W. B. (2001). The job demands-resources model of burnout. Journal of Applied Psychology, 86(3), 499-512.

De Vellis, R. F. (2003). Scale development: Theory and applications. Thousand Oaks, CA: Sage.

Dudek, B. (2008). Pracoholizm - szkodliwy skutek nadmiernego zaangażowania w pracę. Medycyna Pracy, 59(3), 247-254.

Garson, G. D. (2012). Path analysis. Asheboro, NC: Statistical Associates Publishers.

Golińska, L. (2008). Pracoholizm - uzależnienie czy pasja. Warszawa: Diffin.

Green, D. E., Walkey, F. H. i Taylor, A. J. W. (1991). The three-factor structure of the Maslach Burnout Inventory. Journal of Social Behavior and Personality, 6(3), 453-472.

Griffiths, M. D. (2005). Workaholism is still a useful construct. Addiction Research and Theory, 13(2), 97-100.

Guglielmi, D., Simbula, S., Schaufeli W. B. i Depolo, M. (2012). Self-efficacy and workaholism as initiators of the job demands-resources model. Career Development International, 17(4), 375-389.

Hamama, L. (2012). Burnout in social workers treating children as related to demographic characteristics, work environment, and social support. Social Work Research, 36(2), 113-125.

Hornowska, E. i Paluchowski, W. J. (2007). Praca - skrywana obsesja. Wyniki badań nad zjawiskiem pracoholizmu. Poznań: Bogucki Wydawnictwo Naukowe.

Juczyński, Z. (2008). Dylematy i kontrowersje wokół uzależnień. W: J. M. Brzeziński i L. Cierpiałkowska (red.), Zdrowie i choroba. Problemy teorii, diagnozy i praktyki (s. 190-212). Gdańsk: Gdańskie Wydawnictwo Psychologiczne.

Kanai, A., Wakabayashi, M. i Fling, S. (1996). Workaholism among employees in Japanese corporation: An examination based on the Japanese - version Workaholism Scale. Japanese Psychological Research, 38(4), 192-203.

Klinger, E. i Cox, W. M. (2004). Motivation and the theory of current concerns. W: W. M. Cox i E. Klinger (red.), Handbook of motivational counselling: Concepts, approaches, and assessment (s. 3-27). Chichester, UK: Wiley.

Lee, R. T. i Ashforth, B. E. (1996). A meta-analytic examination of the correlates of the three dimensions of job burnout. Journal of Applied Psychology, 81(2), 123-133.

Malinowska, D. (2010). Wybrane motywacyjne i osobowościowe uwarunkowania różnych postaci pracoholizmu. Niepublikowana praca doktorska napisana pod kierunkiem dr hab. Aleksandry Tokarz, Uniwersytet Jagielloński, Kraków.

Malinowska, D. (2014). Pracoholizm. Zjawisko wielowymiarowe. Kraków: Wydawnictwo Uniwersytetu Jagiellońskiego.

Malinowska, D., Jochymek, S. i Tokarz, A. (2011). Zdrowy pracoholizm? Rozważania o złożonej naturze pracoholizmu i jego zwiąkach ze zdrowiem $i$ jakościa życia $w$ różnych obszarach funkcjonowania człowieka. Referat wygłoszony na XXXIV Zjazd Naukowy Polskiego Towarzystwa Psychologicznego, Katowice, Polska. 
Malinowska, D., Tokarz, A. i Gad, N. (2010). Wstępne badania nad adaptacją skali Workaholism Battery (WorkBAT) Spence i Robbins. Studia Psychologiczne, 48(3), 35-42.

Maslach, C. (1982). Burnout: The cost of caring. Englewood Cliffs, NJ: Prentice Hall.

Maslach, C. (1986). Stress, burnout and workaholism. W: R. R. Killberg, P. E. Nathan i R. W. Thoreson (red.), Professionals in distress: Issues, syndromes and solutions inpsychology (s. 53-73). Washington, DC: American Psychological Association.

Maslach, C. (1993/2000). Wypalenie - w perspektywie wielowymiarowej. W: H. Sęk (red.), Wypalenie zawodowe. Przyczyny, mechanizmy, zapobieganie (s. 13-31). Warszawa: Wydawnictwo Naukowe PWN.

Maslach, C. i Jackson, S. E. (1981). The measurement of experienced burnout. Journal of Occupational Behaviour, 2(2), 99-113.

Maslach, C., Jackson, S. E. i Leiter, M. P. (1996). Maslach Burnout Inventory. Manual. Palo Alto, CA: Consulting Psychologists Press.

Maslach, C. i Schaufeli, W. B. (1993). Historical and conceptual development of burnout. W: W. B. Schaufeli, C. Maslach i T. Marek (red.), Professional burnout: Recent developments in theory and research (s. 1-16). Washington: Taylor \& Francis.

Masłowska, E. (2008). System wartości i kody etyczne jako determinanty wypalenia zawodowego nauczycieli i finansistów. Nieopublikowana praca magisterska. Uniwersytet Jagielloński, Kraków.

McMillan, L. H. W., Brady, E. C., O’ Discroll, M. P. i Marsh, N. V. (2002). A mulifaced validation study of Spence and Robbins' (1992) workaholism battery. Journal of Occupational and Organizational Psychology, 75(3), 357-368.

McMillan, L. H. W. i O’Discroll, M. P. (2004). Workaholism and health: Implications for organizations. Journal of Organizational Change Management, 17(5), 509-519.

McMillan, L. H. W., O'Driscoll, M. P. i Brady, E. C. (2004). The impact of workaholism on personal relationships. British Journal of Guidance and Counseling, 32(3), 171-186.

Ng, T. W. H., Sorensen, K. L. i Feldman, D. C. (2007). Dimensions, antecedents, and consequences of workaholism: A conceptual integration and extension. The Construct of Workaholism, 136(1), 111-136.

Patel, A. S., Bowler, M. C., Bowler, J. L. i Methe, S. A. (2012). A meta-analysis of workaholism. International Journal of Business and Management, 7(11), 2-17.

Pines, A. M. (1993). Burnout: An existential perspective. W: W. B. Schaufeli, C. Maslach i T. Marek (red.), Professional burnout: Recent developments in theory and research (s. 33-52). Washington, DC: Taylor \& Francis.

Robinson, B. E. (1999). The Work Addiction Risk Test: Development of a tentative measure of workaholism. Perceptual and Motor Skills, 88(1), 199-210.

Schaufeli, W. B., Bakker, A. B., Hoogduin, K., Schaap, C. i Kladler, A. (2001). On the clinical validity of the Maslach Burnout Inventory and the Burnout Measure. Psychology and Health, 16(5), 565-582.

Schaufeli, W. B., Bakker, A. B., van der Heijden, F. M. M. A. i Prins, J. T. (2009). Workaholism, burnout and well-being among junior doctors: The mediating role of role conflict. Work \& Stress, 23(2), 155-172.

Schaufeli, W. B. i Enzmann, D. (1998). The burnout companion for research and practice: A critical analysis of theory, assessment, research, and interventions. London: Taylor \& Francis. 
Schaufeli, W. B., Leiter, M. P., Maslach, C. i Jackson, S. E. (1996). Maslach Burnout Inventory - General Survey. W: C. Maslach, S. E. Jackson i M. P. Leiter (red.), The Maslach Burnout Inventory - Test Manual (s. 22-26). PaloAlto, CA: Consulting Psychologists Press.

Schaufeli, W. B., Shimazu, A. i Taris, T. W. (2009). Being driven to work exceptionally hard: The evaluation of a two-factor measure of workaholism in the Netherlands and Japan. CrossCultural Research, 43(4), 320-348.

Schaufeli, W. B., Taris, T. W. i van Rhenen, W. (2008). Workaholism, burnout, and work engagement: Three of a kind or three different kinds of employee well-being? Applied Psychology: An International Review, 57(2), 173-203.

Schaufeli, W. B. i van Dierendonck, D. (2000). Handleiding van de Utrechtse Burnout Schaal (UBOS). Lisse, The Netherlands: Swets Test Services.

Smith, D. E. i Seymour, R. B. (2004). The nature of addiction. W: R. H. Coombs (red.), Handbook of addictive disorders: A practical guide to diagnosis and treatment (s. 3-30). New Jersey: John Wiley \& Sons, Inc.

Spence, J. T. i Robbins, A. S. (1992). Workaholism: Definition, measurement, and preliminary Results. Journal of Personality Assessment, 58(1), 160-178.

Szpitalak, M. (2012). Wielowymiarowy Kwestionariusz Oceny Pracoholizmu. Kraków: Wydawnictwo Uniwersytetu Jagiellońskiego.

Taris, T. W., Schaufeli, W. B. i Verhoeven, L. C. (2005). Workaholism in Netherlands: Measurement and implications for job strain and work-nonwork conflict. Applied Psychology: An International Review, 54(1), 37-60.

Tokarz, A., Malinowska, D. i Jochymek, S. (2014). Inwentarz Wykorzystania Czasu (IWCz) jako narzędzie wspomagające pomiar psychologicznych wtaściwości pracy: Opracowanie narzedzia, jego rzetelność i trafność (manuskrypt w przygotowaniu).

Van Beek, I., Hu, Q., Schaufeli, W. B., Taris, T. W. i Schreurs, B. H. J. (2012). For fun, love, or money: What drives workaholic, engaged, and burned-out employees at work? Applied Psychology, 61(1), 30-55.

Van Beek, I., Taris, T. W. i Schaufeli, W. B. (2011). Workaholic and work engaged employees: Dead ringers or worlds apart? Journal of Occupational Health Psychology, 16(4), 468-482.

Van den Broeck, A., Schreurs, B., De Witte, H., Vansteenkiste, M., Germeys, F. i Schaufeli, W. B. (2011). Understanding workaholics' motivations: A self-determination perspective. Applied Psychology: An International Review, 60(4), 600-621.

Wojdyło, K. (2010). Pracoholizm: perspektywa poznawcza. Warszawa: Difin.

Wojdyło, K. (2013). Workcraving - teoria uzależnienia od pracy. Nauka, 3, 8-97. 